\title{
Analysis of the Role of Tariff Concessions in East Asia
}

\author{
Kenichi Kawasaki \\ Badri Narayanan $G$ \\ Houssein Guimbard \\ Arata Kuno
}

November 2016

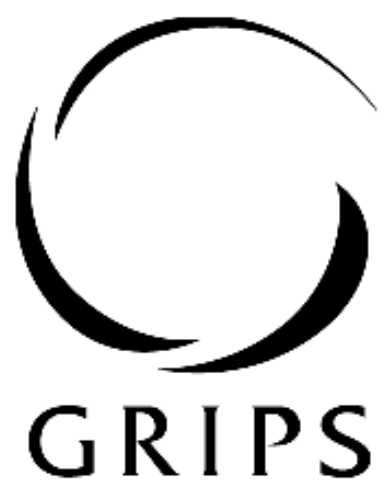

National Graduate institute FOR POLICY STUDIES

National Graduate Institute for Policy Studies

7-22-1 Roppongi, Minato-ku,

Tokyo, Japan 106-8677 


\title{
Analysis of the Role of Tariff Concessions in East Asia ${ }^{1}$
}

\author{
Kenichi Kawasaki ${ }^{2}$ \\ Badri Narayanan $\mathrm{G}^{3}$ \\ Houssein Guimbard ${ }^{4}$ \\ Arata $\mathrm{Kuno}^{5}$
}

\begin{abstract}
While there are many studies focusing on the impacts of various trade policy agreements across the world in the recent years, there is not much focus in the literature on the extent to which these agreements are implemented later, in terms of the aspects agreed upon therein. In this paper, we firstly identify the past achievements of the Economic Partnership Agreements (EPAs) in East Asian regions in terms of tariff removals and suggest future rooms for further economic benefits from trade liberalization in the region. Secondly, we provide the tariff concession dataset in the GTAP Data Base, which distinguishes the tariff removals agreed in these EPAs in East Asia but not implemented yet, from the existing overall tariffs in the benchmark year. As the standard GTAP Data Base only incorporates enforced tariff reductions through the base year applied tariffs, to analyse future trade integration, it might be worth it to integer commitments that are not yet implemented. We do that at the HS6 levels for East Asian EPAs that allows us to compare the economic impacts of partial versus complete implementation of the trade liberalization agreed in East Asian EPAs. Our results suggest that taking those commitments into account economically matters and that such satellite dataset might be taken as actual baseline for future policy simulations.
\end{abstract}

Keywords

RCEP, tariff concession, CGE

JEL classification: D58, F13, F14, F15, F17

1 The earlier version of this study was presented at the 18th Annual Conference on Global Economic Analysis on 17-19 June, 2015 in Melbourne.

2 National Graduate Institute for Policy Studies (GRIPS)

${ }^{3}$ University of Washington Seattle

${ }^{4}$ Centre d'Études Prospectives et d'Informations Internationales (CEPII)

${ }^{5}$ Kyorin University 


\section{Introduction}

The movements of multi-Regional Trade Agreements (RTAs) have accelerated since the beginning of 2013 in Asia-Pacific in addition to bilateral Free Trade Agreements (FTAs). The negotiations on the China-Japan-Korea FTA (CJKFTA) and the Regional Comprehensive Economic Partnership (RCEP) were launched. The Trans-Pacific Partnership (TPP) negotiation was concluded in 2015.

There have been several impact studies on the impacts of East Asian integration employing Computable General Equilibrium (CGE) model simulations, those include Kawasaki (2015), Itakura and Lee (2012), and Petri, Plummer and Zhai (2012). However, there is not much focus in the literature on the extent to which these agreements are implemented later, in terms of the aspects agreed upon therein. This is an emerging key issue for assessing the economic impacts of Mega-RTAs, given numbers of bilateral and sub-regional agreements existing in the regions.

The United States International Trade Commission (USITC) has conducted the most accurate study in this regard reporting the likely impact of TPP on the US economy in May 2016. ${ }^{6}$ It has used the tariff reduction scheduling data for TPP countries in Market Access Map (MAcMap) by the International Trade Centre (ITC) ${ }^{7}$ prepared for the Global Economic Partnership Agreements (EPAs) ${ }^{8}$ Research Consortium ${ }^{9}$. However, those tariff data developments have been limited to EPAs among TPP countries and the extension applying to other EPAs have been under construction.

We identify the past achievements of the EPAs) in East Asian regions in terms of tariff removals and suggest future rooms for further economic benefits from trade liberalization in the region. In the following section 2, after a brief look at Asian regionalism, tariff concessions in Asian EPAs are described by countries and sectors comparing the initial and final levels of tariff protections. Section 3 presents CGE

\footnotetext{
${ }^{6}$ See USITC (2016)

7 http://www.macmap.org/

8 EPAs have intended to mean wider measures in East Asia than FTAs and RTAs including the elements of economic cooperation in addition to trade liberalization.

9 http://www3.grips.ac.jp/ GlobalEPAsResearchConsortium/en/
} 
model simulations estimating the income gains from tariff reductions according to RCEP based on the baseline developed in this paper incorporating the tariff reduction schedules of existing EPAs. The paper concludes with Section 4.

\section{Descriptive evidence}

\subsection{Asian regionalism}

East Asia has been a world growth centre for decades, and the unprecedented development of production networks particularly in the manufacturing sector has been progressing since the 1990s. East Asian countries, especially China and Association of South-East Asian Nations (ASEAN) member countries, have individually adopted aggressive trade and investment-related policies in order to attract foreign direct investment and to utilize the globalizing market forces for achieving higher economic growth. Although these policies were not necessarily well-coordinated among the countries at the beginning, intensive effort toward regional economic integration in the form of EPAs has gradually developed since the 2000s, partially due to the stalled World Trade Organization (WTO) Doha Round.

As presented in Chart 1, in 2000, there were only two EPAs among East Asia countries, namely Australia-New Zealand Closer Economic Relations Trade Agreement (ANZCERTA) and ASEAN Free Trade Area (AFTA), whereas there are thirty EPAs in this region in 2015. This includes several bilateral EPAs as well as five ASEAN+1 EPAs: the ASEAN-China Free Trade Agreement (ACFTA) enforced in 2005, the ASEAN-Korea Free Trade Agreement (AKFTA) in 2007, the ASEAN-Japan Comprehensive Economic Partnership (AJCEP) in 2008, the ASEAN-India FTA (AIFTA) in 2010, and the ASEAN-Australia-New Zealand FTA (AANZFTA) in 2010. In addition to these existing EPAs, the ASEAN-10 and the six FTA partners of the ASEAN are currently engaged in the RCEP negotiation with a view to further strengthen a legal framework for securing de-facto economic integration in this region. Finally, China, Japan, and Korea has been negotiating a possible free trade agreement (CJK FTA) since 2013.

Looking from a different angle, 115 out of 120 possible combinations of bilateral agreements in East Asia are already covered by EPAs concluded or 


\section{Chart 1 Newly enacted EPAs among East Asian countries}

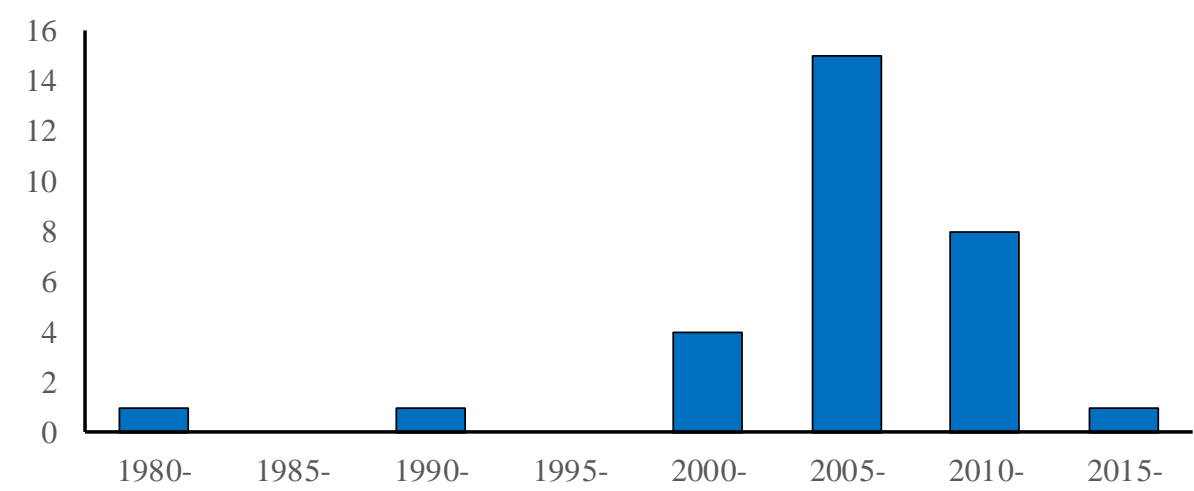

Source: Authors' compilation from various WEB sites

implemented. The remaining five combinations ${ }^{10}$ also have either bilateral or plurilateral EPAs under negotiation such as CJK FTA and RCEP after TPP negotiation concluded in October $2015^{11}$.

On the other hand, as explained in the following section, this doesn't necessarily mean that these EPAs resulted in complete elimination of tariffs among the member countries. It is not unusual for a country to fail to achieve $100 \%$ level of tariff elimination in an EPA negotiation due to politico-economic reasons. No matter how many partners a country enters into EPAs with, if the ratio of liberalized items is limited, then the economic gains from EPAs are likely to fall short of expectations. Therefore, it should be emphasized that conclusion of FTAs alone does not automatically bring the economic benefits to member countries.

\subsection{Tariff concession}

We provide the tariff concession dataset in the Global Trade Analysis Project (GTAP) database, which distinguishes the tariff removals agreed in these EPAs in East Asia but not implemented yet, from the existing overall tariffs in the benchmark year. The standard GTAP Data Base incorporates all in force tariff reductions that have been included in the agreements; however significant liberalization still has to be implemented. We have quantified the actual tariff removals in East Asian EPAs at HS6 levels. These will be aggregated to GTAP sectoral level, to arrive at a GTAP-consistent

10 Australia-India, China-India, India-New Zealand, Japan-China, Japan-Korea.

11 The TPP was signed on February 2016, but is still to be ratified. 
tariff dataset that contains actually implemented tariffs in East Asia. This is suggested to be taken as the actual baseline for policy simulations in the future.

By using a product-level preferential tariff dataset, we construct a new GTAP-compatible dataset of tariff concessions under existing East Asian EPAs. The level of tariff concessions for each sector to which a country is willing to commit is measured by the conventional level of tariff-elimination index (i.e. the share of duty-free tariff lines for a sector after the transition period).

It should be noted that the original tariff data have some inconsistencies across the EPAs and countries for two reasons. First, some EPAs employ HS2002 version of tariff classification in the agreement texts, whereas others employ HS2007 version, depending on the timing of the negotiation. Second, as the most detailed tariff classifications (HS 8-10 digit) are not internationally standardized and are autonomously defined by each country, the total number of tariff lines at HS 8-10 digit level varies from one country to another.

In order to make our data comparable across countries and EPAs, we first compute the share of duty-free tariff lines at HS 6 digit level, and then convert all the HS2002 based tariff data into HS2007 based data, using a correspondence table provided by the World Integrated Trade Solution (WITS) website. ${ }^{12}$ Finally, the data are aggregated to the GTAP sectoral level in order to implement our simulations.

The data on preferential tariffs used in this paper are mainly taken from the ERIA (Economic Research Institute for the Association of ASEAN and East Asia) preferential tariff dataset (Kuno, 2011; Kuno et al, forthcoming), which covers 56 country-level tariff schedules under the five existing ASEAN+1 FTAs: the ASEAN-Australia-New Zealand FTA (AANZFTA), the ASEAN-China FTA (ACFTA), the ASEAN-India FTA (AIFTA), the ASEAN-Japan Comprehensive Economic Partnership (AJCEP) and the ASEAN-Korea FTA (AKFTA). This is supplemented with the data on tariff commitments under the ASEAN Trade in Goods Agreement (ATIGA), which are taken from the ASEAN Secretariat website, as well as the tariff data on some Japan's bilateral EPAs.

12 http://wits.worldbank.org/ 
Table 1 Tariff concessions in East Asian EPAs: number of commodities

\begin{tabular}{|c|c|c|c|c|c|c|c|c|c|c|c|c|c|c|c|c|}
\hline \multirow[t]{2}{*}{ Importers } & \multirow[t]{2}{*}{ Ave." } & \multicolumn{15}{|c|}{ Exporters } \\
\hline & & BRN & KHM & IDN & LAO & MYS & PHL & SGP & THA & VNM & AUS & $\mathrm{CHN}$ & IND & JPN & KOR & NZL \\
\hline BRN & 98.2 & - & 99.2 & 99.2 & 99.2 & 99.2 & 99.2 & 99.2 & 99.2 & 99.2 & 99.3 & 98.4 & 86.2 & 98.2 & 99.2 & 99.3 \\
\hline KHM & 94.6 & 98.5 & - & 98.5 & 98.5 & 98.5 & 98.5 & 98.5 & 98.5 & 98.5 & 90.8 & 90.2 & 88.5 & 85.3 & 91.0 & 90.8 \\
\hline IDN & 93.5 & 98.8 & 98.8 & - & 98.8 & 98.8 & 98.8 & 98.8 & 98.8 & 98.8 & 94.7 & 92.5 & 52.1 & 92.2 & 92.1 & 94.7 \\
\hline LAO & 84.3 & 80.0 & 80.0 & 80.0 & - & 80.0 & 80.0 & 80.0 & 80.0 & 80.0 & 93.1 & 97.7 & 80.3 & 86.8 & 90.1 & 93.1 \\
\hline MYS & 96.3 & 98.9 & 98.9 & 98.9 & 98.9 & - & 98.9 & 98.9 & 98.9 & 98.9 & 97.6 & 93.7 & 80.9 & 95.0 & 93.0 & 97.6 \\
\hline PHL & 89.9 & 99.1 & 99.1 & 99.1 & 99.1 & 99.1 & 0.0 & 99.1 & 99.1 & 99.1 & 96.1 & 92.8 & 82.2 & 97.7 & 90.0 & 96.1 \\
\hline SGP & 100.0 & 100.0 & 100.0 & 100.0 & 100.0 & 100.0 & 100.0 & - & 100.0 & 100.0 & 100.0 & 100.0 & 100.0 & 100.0 & 100.0 & 100.0 \\
\hline THA & 97.2 & 99.8 & 99.8 & 99.8 & 99.8 & 99.8 & 99.8 & 99.8 & - & 99.8 & 98.9 & 93.8 & 78.6 & 96.6 & 95.3 & 98.9 \\
\hline VNM & 82.5 & 75.6 & 75.6 & 75.6 & 75.6 & 75.6 & 75.6 & 75.6 & 75.6 & - & 95.4 & 93.2 & 79.9 & 95.4 & 91.2 & 95.4 \\
\hline AUS & 100.0 & 100.0 & 100.0 & 100.0 & 100.0 & 100.0 & 100.0 & 100.0 & 100.0 & 100.0 & - & n.a. & - & n.a. & n.a. & n.a. \\
\hline $\mathrm{CHN}$ & 95.1 & 95.1 & 95.1 & 95.1 & 95.1 & 95.1 & 95.1 & 95.1 & 95.1 & 95.1 & n.a. & - & - & - & n.a. & n.a. \\
\hline IND & 78.9 & 78.9 & 78.9 & 78.9 & 78.9 & 78.9 & 78.9 & 78.9 & 78.9 & 78.9 & - & - & - & n.a. & n.a. & - \\
\hline JPN & 93.7 & 89.5 & 93.6 & 94.2 & 93.6 & 94.6 & 95.2 & 93.4 & 94.7 & 94.6 & n.a. & - & n.a. & - & - & - \\
\hline KOR & 92.2 & 92.2 & 92.2 & 92.2 & 92.2 & 92.2 & 92.2 & 92.2 & 92.2 & 92.2 & n.a. & n.a. & n.a. & - & - & n.a. \\
\hline NZL & 100.0 & 100.0 & 100.0 & 100.0 & 100.0 & 100.0 & 100.0 & 100.0 & 100.0 & 100.0 & n.a. & n.a. & - & - & n.a. & - \\
\hline
\end{tabular}

* Averages of RCEP countries for ASEAN countries and ASEAN countries for non-ASEAN countries (same in the following tables).

Source: Authors' estimates

East Asian EPAs have "substantially covered" almost all commodities for tariff reductions, ranging from around $80 \%$ in India to $100 \%$ in Singapore, Australia and New Zealand (Table 1).

\subsection{Countries' tariff protection}

\subsubsection{Initial tariff protection}

To be consistent with the year of calibration of the GTAP model, we stick to 2011 tariff data for descriptive purposes. This initial point is not the most recent, but it gives a rather closed picture of the actual situation (see Table 2). It presents the average tariffs (in ad valorem equivalent, AVE) applied by each country to its partners. The column "Ave." refers by each ASEAN countries to all its regional partners and to the average tariff applied by each of the six remaining countries to the ASEAN10. To provide an overview of trade preferences within those countries, we also provide a table with the same structure, displaying most favoured nation (MFN) tariff rates (see Table A1 in appendix).

Countries belonging to the region are rather heterogeneous in terms of development and their tariff patterns classically reproduce what is observed at the world level: developed countries are less protectionist than developing countries. Australia $(0.34 \%)$, New Zealand (0.74\%) and Japan (1.38\%) apply the lowest level of tariffs to ASEAN countries. 
Table 2 Bilateral AVEs of average applied tariffs, 2011

\begin{tabular}{|c|c|c|c|c|c|c|c|c|c|c|c|c|c|c|c|c|}
\hline \multirow[t]{2}{*}{ Importers } & \multirow[t]{2}{*}{ Ave." } & \multicolumn{15}{|c|}{ Exporters } \\
\hline & & BRN & КHM & IDN & $\mathrm{LAO}$ & MYS & PHL & SGP & THA & VNM & AUS & $\mathrm{CHN}$ & IND & JPN & KOR & NZL \\
\hline BRN & 2.7 & - & 1.3 & 4.3 & 1.1 & 3.0 & 3.4 & 2.1 & 5.6 & 0.5 & 2.6 & 3.9 & 0.4 & 8.0 & 2.3 & 1.8 \\
\hline KHM & 11.6 & 14.2 & - & 6.5 & 13.9 & 11.7 & 11.1 & 15.6 & 12.7 & 12.9 & 10.8 & 10.1 & 8.3 & 16.5 & 11.1 & 11.2 \\
\hline IDN & 2.1 & 0.0 & 0.0 & - & 0.0 & 0.2 & 0.3 & 0.2 & 1.3 & 1.8 & 4.6 & 1.2 & 3.7 & 7.2 & 1.4 & 4.4 \\
\hline LAO & 8.6 & 2.6 & 15.2 & 5.7 & - & 3.8 & 3.4 & 20.0 & 6.9 & 3.1 & 7.6 & 10.2 & 16.2 & 19.8 & 24.7 & 6.3 \\
\hline MYS & 3.8 & 1.8 & 8.0 & 1.7 & 0.1 & - & 1.3 & 1.0 & 1.6 & 4.0 & 2.6 & 3.6 & 4.4 & 8.9 & 6.4 & 2.6 \\
\hline PHL & 2.1 & 0.0 & 0.4 & 0.0 & 0.0 & 0.1 & - & 0.0 & 2.8 & 20.3 & 1.1 & 0.9 & 7.9 & 2.0 & 1.3 & 0.9 \\
\hline SGP & 0.0 & 0.0 & 0.0 & 0.0 & 0.0 & 0.0 & 0.0 & - & 0.0 & 0.0 & 0.0 & 0.0 & 0.0 & 0.0 & 0.0 & 0.0 \\
\hline THA & 7.4 & 0.1 & 14.0 & 8.9 & 2.9 & 5.7 & 10.1 & 6.2 & - & 9.1 & 3.1 & 6.8 & 7.8 & 8.8 & 6.2 & 8.5 \\
\hline VNM & 6.3 & 0.0 & 5.1 & 3.2 & 0.5 & 3.0 & 2.7 & 7.4 & 3.9 & - & 3.5 & 7.5 & 8.6 & 5.2 & 6.8 & 4.8 \\
\hline AUS & 0.3 & 0.0 & 0.0 & 2.1 & 0.0 & 0.2 & 0.1 & 0.0 & 0.0 & 0.1 & - & n.a. & - & n.a. & n.a. & n.a. \\
\hline $\mathrm{CHN}$ & 1.5 & 0.0 & 2.7 & 1.4 & 1.8 & 1.0 & 0.2 & 0.4 & 2.4 & 4.6 & n.a. & - & - & - & n.a. & n.a. \\
\hline IND & 17.9 & 0.1 & 39.9 & 31.6 & 0.1 & 20.3 & 5.9 & 4.0 & 9.1 & 11.3 & - & - & - & n.a. & n.a. & - \\
\hline JPN & 1.4 & 0.0 & 0.2 & 0.3 & 0.6 & 0.3 & 1.2 & 3.1 & 4.3 & 1.0 & n.a. & - & n.a. & - & - & - \\
\hline KOR & 4.0 & 2.3 & 10.9 & 1.8 & 0.4 & 2.1 & 4.2 & 1.2 & 12.7 & 10.2 & n.a. & n.a. & n.a. & - & - & n.a. \\
\hline NZL & 0.7 & 0.0 & 0.0 & 1.7 & 0.0 & 0.9 & 1.4 & 0.0 & 1.5 & 2.6 & n.a. & n.a. & - & - & n.a. & - \\
\hline
\end{tabular}

According to the trade structure and the level of initial tariff, average protection varies across partners for a given importer. Thus, the country that faces the highest protection when exporting to Australia is Indonesia (2.1\%). The other Australian partners face very low average tariffs (less than $0.2 \%$ in average). Protection in New Zealand exhibits a little variance, from free trade (which Brunei, Cambodia, Lao and Singapore benefit) to $2.6 \%$ applied to Vietnamese products. Japan applies low tariffs to its ASEAN neighbors, excepting Thailand which faces a $4.3 \%$ average tariff.

China applies a fairly low level of protection to its ASEAN partners: $1.5 \%$. Only Thailand (2.4\%), Cambodia (2.7\%) and Vietnam (4.6\%) encounter average duties that are greater than $2 \%$.India (17.9\%) and Korea (4\%) are globally more protectionist than their ASEAN partners. India remains the most protectionist country in the region, even if, since, mid-2000s, it has considerably reduced its custom duties. Cambodia is the ASEAN country that has the most limited market access to China (39.9\%), followed by Indonesia (31.6\%) and Malaysia (20.3\%).

Regarding ASEAN countries, those applying high duties inside the ASEAN block are the ASEAN4, that is Cambodia (11.6\%), Lao (8.6\%) and Vietnam $(6.3 \%)^{13}$, as a result of their longer tariff dismantlement schedule within the ASEAN10, due to their lower level of development. Malaysia applies an average tariff of 3.8\%, to its regional partners. The rest of ASEAN countries apply intra-ASEAN tariffs lower, in average. Their openness to the "Six" is also limited, some countries being very protectionist, as

13 Myanmar is not considered in the tariff descriptive analysis as it belongs to a composite GTAP area. 
Table 3 Bilateral average AVEs of applied tariffs after EPAs' implementation

\begin{tabular}{|c|c|c|c|c|c|c|c|c|c|c|c|c|c|c|c|c|}
\hline \multirow[t]{2}{*}{ Importers } & \multirow[t]{2}{*}{ Ave." } & \multicolumn{15}{|c|}{ Exporters } \\
\hline & & BRN & KHM & IDN & $\mathrm{LAO}$ & MYS & PHL & SGP & THA & VNM & AUS & $\mathrm{CHN}$ & IND & JPN & KOR & NZL \\
\hline BRN & 0.5 & - & 0.0 & 0.0 & 0.0 & 0.1 & 0.0 & 0.4 & 0.0 & 0.0 & 0.3 & 2.1 & 0.1 & 0.7 & 0.1 & 0.4 \\
\hline KHM & 3.9 & 0.0 & - & 0.1 & 0.4 & 0.3 & 0.1 & 5.3 & 2.2 & 4.7 & 6.2 & 3.1 & 2.1 & 12.3 & 8.2 & 5.8 \\
\hline IDN & 0.9 & 0.0 & 0.0 & - & 0.0 & 0.1 & 0.3 & 0.1 & 1.3 & 1.8 & 0.9 & 0.9 & 3.1 & 1.8 & 0.9 & 0.6 \\
\hline LAO & 6.0 & 1.7 & 14.6 & 4.7 & - & 2.9 & 2.1 & 19.3 & 6.2 & 2.5 & 2.0 & 0.8 & 13.1 & 14.3 & 23.1 & 0.5 \\
\hline MYS & 1.4 & 0.0 & 8.0 & 0.9 & 0.0 & - & 1.1 & 0.5 & 0.8 & 2.9 & 1.1 & 1.3 & 2.8 & 1.8 & 3.4 & 0.4 \\
\hline PHL & 1.7 & 0.0 & 0.4 & 0.0 & 0.0 & 0.1 & - & 0.0 & 2.8 & 20.3 & 0.4 & 0.8 & 5.3 & 1.1 & 0.6 & 0.2 \\
\hline SGP & 0.0 & 0.0 & 0.0 & 0.0 & 0.0 & 0.0 & 0.0 & - & 0.0 & 0.0 & 0.0 & 0.0 & 0.0 & 0.0 & 0.0 & 0.0 \\
\hline THA & 2.0 & 0.0 & 0.0 & 0.0 & 0.0 & 0.0 & 0.0 & 0.0 & - & 0.9 & 0.1 & 1.3 & 4.9 & 4.2 & 1.3 & 0.8 \\
\hline VNM & 2.9 & 0.0 & 4.8 & 2.3 & 0.4 & 2.2 & 1.9 & 7.2 & 3.2 & & 1.8 & 2.2 & 3.5 & 1.6 & 3.2 & 0.9 \\
\hline AUS & 0.0 & 0.0 & 0.0 & 0.0 & 0.0 & 0.0 & 0.0 & 0.0 & 0.0 & 0.0 & - & n.a. & - & n.a. & n.a. & n.a. \\
\hline CHN & 1.2 & 0.0 & 2.7 & 1.3 & 1.8 & 0.8 & 0.1 & 0.3 & 2.0 & 2.9 & n.a. & - & - & - & n.a. & n.a. \\
\hline IND & 15.2 & 0.1 & 39.4 & 29.0 & 0.0 & 17.4 & 1.6 & 2.0 & 5.6 & 7.0 & - & - & - & n.a. & n.a. & - \\
\hline JPN & 0.9 & 0.0 & 0.1 & 0.3 & 0.4 & 0.3 & 0.6 & 2.9 & 2.6 & 0.5 & n.a. & - & n.a. & - & - & - \\
\hline KOR & 2.3 & 0.0 & 4.4 & 0.5 & 0.2 & 0.6 & 2.8 & 0.4 & 10.8 & 6.2 & n.a. & n.a. & n.a. & - & - & n.a. \\
\hline NZL & 0.0 & 0.0 & 0.0 & 0.0 & 0.0 & 0.0 & 0.0 & 0.0 & 0.0 & 0.0 & n.a. & n.a. & - & - & n.a. & - \\
\hline
\end{tabular}

Cambodia, Lao or Thailand. Thus, bilateral levels of protection are asymmetrical, witnessing the progresses that can be made on the reciprocity of the EPAs: ASEAN countries apply higher tariffs in average to Australia, China, Japan and New Zealand than the opposite. Lastly, in 2011, Singapore appears as an extreme case as it is completely opened to all its partners in the region.

\subsubsection{Final tariff protection within EPAs}

Tariffs dismantlement within ASEAN and EPAs is still ongoing. Merging the information on the remaining of products whose duties still require to be removed within this framework, as explained in section 1, and actual tariffs makes it possible to compute the final tariff level, product by product, for each bilateral relationship.

The full implementation of EPAs produces a different picture of the average protection in the region and between countries. Table 3 provides an overview of the situation in 2025 , i.e. once all commitments are implemented.

Comparing the initial and the final level of tariffs allows us to evaluate the tariff liberalization that will occur in those agreements. Tariff concessions in East Asian EPAs have not always been substantially high enough in terms of average tariff rates (Table 4), those would be much more effective than number of commodities (Table 1).

On the ASEAN countries' side, tariff protection decreases greatly when taking into account all commitments (except for Singapore which is already fully opened). Cambodia reduces spectacularly its average tariffs by more than 7.5 percentage points 
Table 4 Tariff concessions in East Asian EPAs: tariff rates

\begin{tabular}{|c|c|c|c|c|c|c|c|c|c|c|c|c|c|c|c|c|}
\hline \multirow[t]{2}{*}{ Importers } & \multirow[t]{2}{*}{ Ave. } & \multicolumn{15}{|c|}{ Exporters } \\
\hline & & BRN & KHM & IDN & LAO & MYS & PHL & SGP & THA & VNM & AUS & $\mathrm{CHN}$ & IND & JPN & KOR & NZL \\
\hline BRN & 80.3 & - & 100.0 & 99.8 & 100.0 & 97.3 & 100.0 & 78.8 & 100.0 & 100.0 & 87.5 & 46.4 & 69.0 & 91.7 & 93.8 & 80.8 \\
\hline KHM & 66.6 & 100.0 & - & 98.8 & 97.1 & 97.4 & 99.3 & 66.0 & 82.4 & 63.4 & 42.9 & 68.9 & 74.8 & 25.2 & 26.7 & 48.3 \\
\hline IDN & 57.5 & - & - & - & - & 70.0 & 0.0 & 56.3 & 3.8 & 0.0 & 79.7 & 26.1 & 16.3 & 74.8 & 38.5 & 87.5 \\
\hline LAO & 30.3 & 36.4 & 4.2 & 16.1 & - & 23.2 & 37.3 & 3.3 & 9.1 & 19.0 & 73.8 & 92.0 & 19.1 & 27.6 & 6.3 & 92.7 \\
\hline MYS & 63.4 & 100.0 & 1.1 & 43.6 & 100.0 & - & 11.6 & 56.7 & 46.8 & 27.0 & 58.8 & 65.0 & 36.0 & 79.6 & 46.5 & 85.7 \\
\hline PHL & 17.8 & - & 0.0 & - & - & 0.0 & - & 0.0 & 0.0 & 0.0 & 62.2 & 7.7 & 33.8 & 45.2 & 55.8 & 81.2 \\
\hline SGP & - & - & - & - & - & - & - & - & - & - & - & - & - & - & - & - \\
\hline THA & 73.5 & 100.0 & 100.0 & 99.7 & 99.7 & 99.8 & 100.0 & 100.0 & - & 90.4 & 98.1 & 81.1 & 36.7 & 52.3 & 78.5 & 90.5 \\
\hline VNM & 54.4 & 0.0 & 5.7 & 28.3 & 12.5 & 28.6 & 29.1 & 3.5 & 19.0 & - & 50.1 & 71.2 & 59.7 & 70.3 & 52.4 & 81.8 \\
\hline AUS & 100.0 & 100.0 & - & 100.0 & - & 100.0 & 100.0 & - & 100.0 & 100.0 & - & n.a. & - & n.a. & n.a. & n.a. \\
\hline $\mathrm{CHN}$ & 21.2 & - & 1.5 & 9.2 & 0.6 & 19.2 & 45.5 & 32.4 & 17.2 & 35.5 & n.a. & - & - & - & n.a. & n.a. \\
\hline IND & 15.2 & 16.7 & 1.2 & 8.5 & 60.0 & 14.2 & 73.2 & 49.9 & 38.1 & 37.6 & - & - & - & n.a. & n.a. & - \\
\hline JPN & 34.1 & - & 62.5 & 19.4 & 37.7 & 12.5 & 52.4 & 8.9 & 40.3 & 49.0 & n.a. & - & n.a. & - & - & - \\
\hline KOR & 41.7 & 100.0 & 59.4 & 71.8 & 54.1 & 72.8 & 34.7 & 70.1 & 15.2 & 39.6 & n.a. & n.a. & n.a. & - & - & n.a. \\
\hline NZL & 100.0 & - & - & 100.0 & - & 100.0 & 100.0 & - & 100.0 & 100.0 & n.a. & n.a. & - & - & n.a. & - \\
\hline
\end{tabular}

(hereafter pp), that is to say the average level is almost divided by 3 . This country becomes very opened to its ASEAN neighbor (except vis-à-vis Singapore which still face more than $5 \%$ of average tariff when exporting to Cambodia). Thailand is also another country that experiences a large decrease in its tariff protection (from $7.4 \%$ to $2.0 \%)$. Brunei also reduces significantly its tariffs and stabilizes its average protection to $0.5 \%$ within the region. By implementing more ambitious commitments, Indonesia becomes more liberalized than Philippines. Both countries start with the same level of average protection $(2.1 \%)$ but Indonesia ends with less than $1 \%$ whereas the level of protection of Philippines is $1.7 \%$. Lao remains the most protectionist country in ASEAN: its average protection is $6 \%$ in average, after a decline of $2.6 \mathrm{pp}$. Vietnam more than halves its average protection (from $6.3 \%$ to $2.9 \%$ ) and applies then a reasonable level of average custom duties, but it also remains a country that faces high tariffs when exporting to its partners (for example to Cambodia, Indonesia, Philippines or Thailand).

Regarding the external 6 partners, Australia and New Zealand, which apply very low initial duties to ASEAN countries, now become completely opened to them. The openness is also important for Korea (from $4.0 \%$ to $2.3 \%$ ) and Japan (from $1.4 \%$ to $0.9 \%)$. The ambition is moderated for India: average applied tariff remains high $(15.2 \%)$ but undergoes a decrease by $2.7 \mathrm{pp}$. Finally, China offers the less additional openness to ASEAN countries ( $-0.3 \mathrm{pp}$ ), but the country applies fairly low custom duties to its ASEAN partners (1.2\%) after implementation of its commitments. Asymmetries between ASEAN countries and their partners decrease along with the implementation of existing commitments. Except for India, ASEAN countries remains, however, more protected vis-à-vis the "six" whereas than the opposite. 
Finally, removing of tariff peaks (see table A2 in appendix) is not that ambitious as, once commitments are implemented. Indeed, even if it remains only 7,801 duty lines exhibiting ad valorem equivalent of applied tariffs greater than $30 \%$, Cambodia dramatically cut its tariff peaks as there remain only 1,006 of such tariffs, and so does Thailand (1,946 to 314) Vietnam (from 1,339 to 669) or, to a lesser extent, Brunei (from 255 to 129) and Lao (from 1,320 to 956). Other countries' commitments are less ambitious: some countries almost do not cut or remove these tariffs (e.g. Indonesia or Malaysia) and Philippines do not cut at all its tariff peaks. On ASEAN's partners' side, ambition is moderated (China, India, Japan and Korea). Last, Australia and New Zealand remove the few they had.

\subsection{Sectoral tariff protection}

The average applied protection applied within ASEAN10 and their EPAs partners is, in average, $3.4 \%$ in 2011. The relatively low average hides however a heterogeneous average sectoral tariff protection.

Within the region, agricultural trade is more protected in average $(15.8 \%)$ than industrial trade $(2.4 \%)$. However, some countries present some particularities: Australia and New Zealand protect more their industry $(0.3 \%$ and $0.8 \%$, respectively) than the agricultural sector $(0.1 \%$ and $0.4 \%$ respectively). This remains an exception at the world level, the agriculture being generally protected by higher custom duties (especially specific tariffs or tariff rate quotas) than the industry, witnessing the important competitive advantages those two countries have in these sectors.

The other ASEAN10's partners follow the classical pattern observed worldwide: They clearly protect their agriculture with substantial custom duties. India (73.2\% in agriculture, $4.9 \%$ in Non-agricultural Market Access (NAMA), i.e. industrial products) and Korea (41.6\% and $1.9 \%$ ) highly defend their internal markets, followed by Japan $(18.5 \%$ and $0.2 \%)$. China is relatively the more opened countries, as its average tariff in agriculture is equal to $8.7 \%$ ( $0.8 \%$ in industry).

Protection within the ASEAN10 is more homogenous: the average tariff in industry is half its level in agriculture, as for Brunei (the ratio average agricultural tariff on average industrial tariff is equal to 2.3), Indonesia (2.9), Thailand (2.5) or Malaysia 
(2.1). Lao (1.5) and Vietnam (1.7) exhibit even lower differences between the two sectors. Finally, Cambodia's tariffs do not offer large variability at this sectoral level of aggregation, but as Australia and New Zealand, its agriculture market is more opened than its industrial one: the country applies, in average, $11.6 \%$ in industry and $11.1 \%$ in agriculture.

Finally, even if a part of tariffs has already been removed (witnessed by the preferential margins one can see when comparing MFN tariffs and applied tariffs, see Table A2 in appendix), countries still highly protect a bunch of sensitive products. The number of tariff peaks (i.e. we choose an arbitrary value of the ad valorem equivalent of $30 \%$ to define tariff peaks. Other values can also be found in the literature $(50 \%, 100 \%)$ or on international organizations' websites - e.g. 15\%) is as high as 23,436 (on 656,349 duty lines, once excluding products for which MFN duty is null). 10,416 concern the agricultural sector and non-agricultural market access have 13,020 of such tariffs. Cambodia is the one which use them the most frequently $(13,328$ duty lines, of which 10,052 for industrial products). Australia and New Zealand have a few of those (respectively 8 and 3, all of them applied to manufactured products). Other details can be found in annex.

The first important thing to notice in Table 5 is the ambition of liberalization exhibited by the EPAs: average tariff will go down by $49 \%$ (from $3.4 \%$ in 2011 to $1.7 \%$ once EPAs are implemented). Among the 43 GTAP sectors, 31 see their average tariffs reduced by more than a half. Five sectors experience a decline comprised between $25 \%$ and $50 \%$ and only seven are liberalized by less than a quarter.

On the 31 most liberalized sectors, the tariffs of five of them are completely removed $(-100 \%)$. However, these sectors have initially a very little average protection and concern mainly energy-related products. Two other sectors are also in this case: the sector "Wool" whose initial average tariff is not very high $(2.2 \%)$ and the "sugar cane" sector $(0.2 \%)$ are fully liberalized.

Among the sectors with a significant drop in their protection and having an initial average tariff relatively important, the sectors related to the textile industry see their tariffs importantly removed: the "Wearing apparel" sector starts with a 8.8\% average tariff that is reduced by $-92.2 \%$, the "textiles" sectors is protected by $5.7 \%$ that will be substantially reduced $(-70.5 \%)$ and the "Leather products" $(6.1 \%$ in 2011$)$ will 
Table 5 Average AVEs of applied tariffs in 2011 and after EPAs' implementation, by GTAP sectors

\begin{tabular}{|c|c|c|c|c|}
\hline GTAP Code & Sector & Applied 2011 & Applied 2025 & Delta \\
\hline gdt & Gas manufacture and distribution & 0.0 & 0.0 & -100 \\
\hline oil & Oil & 0.5 & 0.0 & -100 \\
\hline wol & Wool. Silk-worm cocoons & 2.2 & 0.0 & -100 \\
\hline$c \_b$ & Sugar cane and sugar beet & 0.2 & 0.0 & -100 \\
\hline gas & Gas & 0.2 & 0.0 & -100 \\
\hline $\mathrm{col}$ & Coal & 0.6 & 0.0 & -99.9 \\
\hline for & Forestry & 2.4 & 0.1 & -95.8 \\
\hline ele & Electronic equipment & 0.4 & 0.0 & -92.5 \\
\hline wap & Wearing apparel & 8.8 & 0.7 & -92.2 \\
\hline oap & Animal products NEC & 3.8 & 0.4 & -90.1 \\
\hline wht & Wheat & 6.0 & 0.7 & -87.6 \\
\hline omn & Minerals NEC & 0.3 & 0.0 & -87.6 \\
\hline $\mathrm{nfm}$ & Metals NEC & 1.1 & 0.1 & -87.2 \\
\hline fmp & Metal products & 5.2 & 0.7 & -86.6 \\
\hline ppp & Paper products. Publishing & 2.4 & 0.4 & -83.6 \\
\hline ome & Machinery and equipment NEC & 2.5 & 0.4 & -82.3 \\
\hline omf & Manufactures NEC & 3.8 & 0.8 & -79.0 \\
\hline $\mathrm{cmt}$ & Meat: Cattle, sheep, goats and horses & 8.4 & 1.8 & -78.6 \\
\hline tex & Textiles & 5.7 & 1.7 & -70.5 \\
\hline osd & Oil seeds & 5.9 & 1.8 & -69.0 \\
\hline mil & Dairy products & 4.0 & 1.3 & -67.3 \\
\hline otn & Transport equipment NEC & 3.3 & 1.1 & -67.2 \\
\hline $\mathrm{ctl}$ & Cattle, sheep, goats and horses & 2.5 & 0.8 & -66.7 \\
\hline $\mathrm{nmm}$ & Mineral products NEC & 4.0 & 1.4 & -63.8 \\
\hline $\mathrm{pfb}$ & Plant-based fibers & 0.0 & 0.0 & -63.7 \\
\hline lea & Leather products & 6.1 & 2.2 & -63.6 \\
\hline fsh & Fishing & 1.9 & 0.7 & -63.1 \\
\hline $\operatorname{crp}$ & Chemical, rubber and plastic products & 2.9 & 1.1 & -62.4 \\
\hline i_s & Ferrous metals & 5.5 & 2.1 & -62.0 \\
\hline lum & Wood products & 3.1 & 1.4 & -56.5 \\
\hline gro & Cereal grains NEC & 5.1 & 2.5 & -51.0 \\
\hline ofd & Food products NEC & 7.5 & 3.8 & -48.7 \\
\hline mvh & Motor vehicles and parts & 12.9 & 7.6 & -40.7 \\
\hline p_c & Petroleum and coal products & 1.2 & 0.8 & -33.7 \\
\hline $\mathrm{pdr}$ & Paddy rice & 11.4 & 8.0 & -29.5 \\
\hline omt & Meat products nec & 8.4 & 6.2 & -26.1 \\
\hline v_f & Vegetables, fruit and nuts & 12.1 & 9.5 & -21.6 \\
\hline b_t & Beverages and tobacco products & 22.6 & 19.2 & -15.2 \\
\hline ocr & Crops NEC & 12.4 & 10.5 & -14.8 \\
\hline pcr & Processed rice & 39.9 & 34.8 & -12.9 \\
\hline sgr & Sugar & 15.8 & 14.3 & -9.7 \\
\hline vol & Vegetable oils and fats & 25.6 & 25.1 & -2.1 \\
\hline ely & Electricity & 0.5 & 0.5 & 0 \\
\hline \multicolumn{2}{|r|}{ ALL } & 3.4 & 1.7 & -49.0 \\
\hline
\end{tabular}

Source: ITC's MAcMap database, trade weighted average, \%. Authors' calculations

see its average protection declining by $63.1 \%$. Some agricultural sectors are also significantly liberalized. This is particularly the case for the sector "Animal products NEC" (3.8\% in 2011, $-90.1 \%$ after EPAs' implementation), "wheat" $(6 \%,-87.6 \%)$ and 
the "white meat" sector $(8.4 \%,-78.6 \%)$.

However, the least significant declines also concern agricultural products and especially the sectors in which initial protection was strongest. The "processed rice" sector, for example, which has an initial protection of almost $40 \%$, will still be highly protected after the implementation of the EPAs (the variation corresponds to $-12.9 \%$ ), the sector "vegetable oils and fats" $(25.6 \%,-2.1 \%)$, the "tobacco and alcohol" $(22.6 \%$ $-15.2 \%)$ or the "sugar" products $(15.8 \%,-9.7 \%)$.

\section{Scenarios and simulations}

\subsection{The framework of a CGE model}

Using our specific dataset, we compare the economic impacts of partial versus complete implementation of trade liberalization agreed in East Asian EPAs. To analyze the economy-wide impact of trade liberalization, a CGE model of global trade is employed for the model simulations in this paper. The GTAP standard model, as well as the GTAP database, are utilized as a basis for the simulation experiments in this paper.

A common criticism has often been that a standard CGE model focuses on the evaluation of static efficiency improvements and therefore the dynamic effects among production, income, and savings and investment are not captured. In fact, concerning the dynamic impact of trade liberalization, the growth effects through productivity gains and capital accumulation have been pointed out. In this paper, certain dynamic aspects are studied in the model simulations.

One deals with the dynamic aspects of capital formation by modifying the standard version of the GTAP model. Two mechanisms are considered in this paper. First, the important "dynamic" effects of capital accumulation are introduced into the standard static model. The initial increase in income is assumed to increase savings (a fixed proportion of additional income is saved) and investment. The induced savings and investment (larger capital stock) in turn link to production capacities and cause a further increase in income. Second, the trade balance is endogenously determined and international capital movement is allowed. It is assumed that the expected rate of return on capital is equalized among regions. 
Table 6 Geographical and sectoral aggregations

\begin{tabular}{llll} 
Countries and Regions & Commodities \\
\hline JPN & Japan & RIC & Rice \\
CHN & China & GRA & Grains \\
KOR & Korea & MET & Bovine cattle, sheep and goat products \\
HKG & Hong Kong, China & MIL & Dairy products \\
TWN & Chinese Taipei & SGR & Sugar \\
BRU & Brunei & B_T & Beverages and tobacco products \\
IDN & Indonesia & OAF & Other primary \\
MYS & Malaysia & OPF & Other processed foods \\
PHL & Philippines & MNG & Mining \\
SGP & Singapore & TXL & Textiles and wearing apparel \\
THA & Thailand & CHM & Chemical products \\
VNM & Viet Nam & MTL & Metals \\
KHM & Cambodia & MVH & Motor vehicles and parts \\
LAO & Laos & OTN & Other transport equipment \\
IND & India & ELE & Electronic equipment \\
AUS & Australia & OME & Other machinery and equipment \\
NZL & New Zealand & OMF & Other manufacturing \\
USA & US & CNS & Construction \\
CAN & Canada & EGW & Electricity, gas and water \\
MEX & Mexico & T_T & Transportation \\
CHL & Chile & OSP & Other private services \\
PER & Peru & OSG & Public services \\
RUS & Russia & & \\
EUM & EU & & \\
OAO & Other Asia & & \\
OAM & Other America & & \\
ROW & Rest of the world & & \\
SOurce: & Autors conpiltions & \\
& &
\end{tabular}

Source: Authors' compilation based on GTAP Data Base version 9.0

In addition to these, pro-competitive productivity growth effects are also investigated in the model simulations. It is assumed that the productivity of domestic industries increases in order to compensate for the lower import prices. Such a rate of productivity increase is set as equal to the rates of change in import prices weighted by the proportion of imports over total production, including domestic goods.

\subsection{Scenarios}

The GTAP Database provides well-arranged data on countries and regions in Asia-Pacific, such as Asian newly industrializing economies and ASEAN countries. One notable distinguishing feature of the model is its function to evaluate separately mutual dependence among the Asia-Pacific Economic Cooperation (APEC) economies. The current GTAP Data Base (version 9.0, documented in Narayanan et al, 2015) consists of 57 disaggregated sectors and 140 economies, which are aggregated into the 
appropriate version for the simulations. In this paper, as shown in Table 6, economies are aggregated into 27 regions, of which 20 regions are allocated to the APEC economies. The APEC economies are disaggregated individually where data are available (note that data on Papua New Guinea is unavailable). Commodities are aggregated into 22 sectors in accordance with the medium classifications of standard national accounts, while several sensitive commodities in the primary and food sectors are further disaggregated to some extent.

The latest GTAP Database was released in May 2015. However, its base year remains 2011. The benchmark data used in this study were updated to 2015 in order to reflect the recently growing number of states counted in the world economy. Those data were downloaded from the Data and Statistics section of the website of the International Monetary Fund.

We have simulated two scenarios of unilateral import tariff reductions of East Asian countries from trade partners in the region. The first one is a stylized one where import tariffs existed in 2011 would fully be removed. The second one is to reduce import tariffs based on existing East Asian EPAs discussed above.

\subsection{Results}

According to conventional simulations carried out by using a CGE model of global trade, EPA measures including tariff reductions will stimulate trade by lowering the prices of tradable goods. This will result in increases in the national output of exporting countries while increasing access to the market for trading partners. Meanwhile, domestic production resources-land, capital, labor, and intermediate inputs-will be used more efficiently in importing countries, particularly when domestic distortions, including those due to trade barriers, are reduced. These combined effects - one from foreign markets and the other from the domestic market-are expected to result in the expansion of production and an increase in income and welfare. In addition, economic benefits would expand dynamically through capital formation mechanisms and productivity improvements. Although negative impacts due to trade diversion effects and terms of trade effects are suggested by theoretical studies, empirical analyses, including model simulations, have generally indicated the macroeconomic benefits of EPAs. 


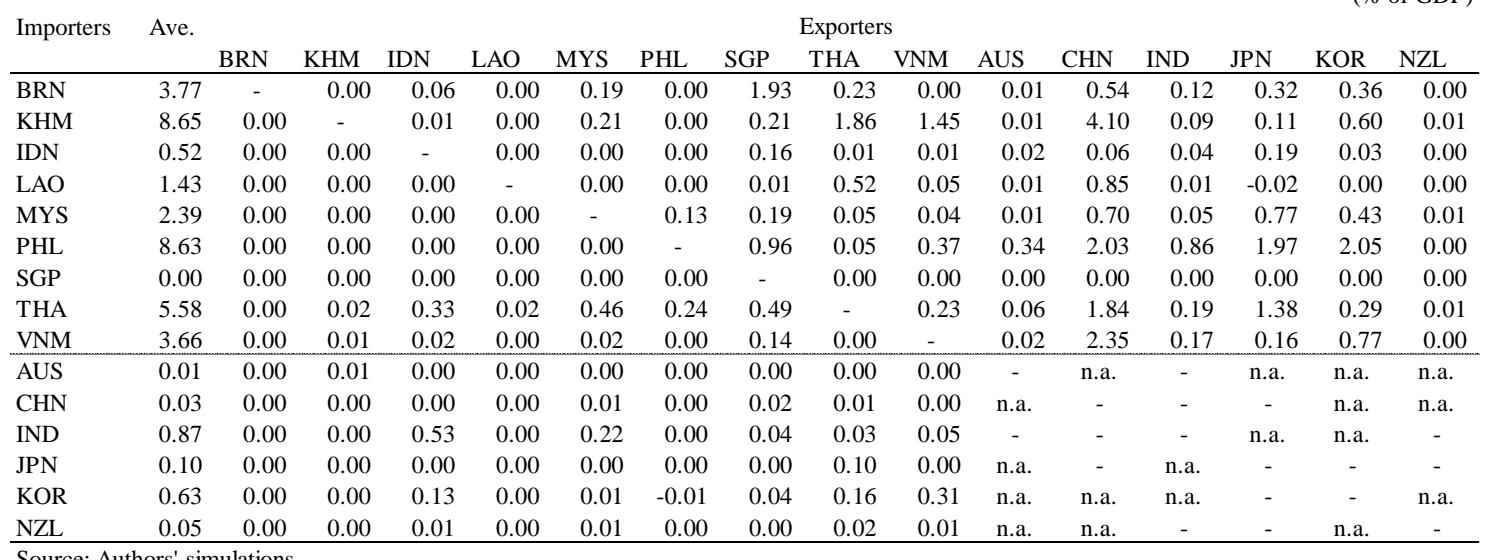

Source: Authors' simulations

Table 8 Changes in equivalent variations according to EPAs tariff reductions

(\% of GDP)

\begin{tabular}{lccccccccccccccccccc} 
Importers & Ave. & \multicolumn{1}{c}{ 1 } & BRN & KHM & IDN & LAO & MYS & PHL & SGP & THA & VNM & AUS & CHN & IND & JPN & KOR & NZL \\
\hline BRN & 1.39 & - & 0.00 & 0.04 & 0.00 & 0.10 & 0.00 & 0.28 & 0.20 & 0.00 & 0.00 & 0.13 & 0.05 & 0.26 & 0.32 & 0.00 \\
KHM & 6.81 & 0.00 & - & 0.01 & 0.00 & 0.21 & 0.00 & 0.21 & 1.86 & 1.45 & 0.00 & 2.81 & 0.06 & 0.00 & 0.19 & 0.00 \\
IDN & 0.14 & 0.00 & 0.00 & - & 0.00 & 0.00 & 0.00 & 0.00 & 0.00 & 0.00 & 0.02 & 0.01 & 0.00 & 0.08 & 0.02 & 0.00 \\
LAO & 1.05 & 0.00 & 0.00 & 0.00 & - & 0.00 & 0.00 & 0.00 & 0.17 & 0.03 & 0.01 & 0.82 & 0.01 & 0.02 & 0.01 & 0.00 \\
MYS & 1.32 & 0.00 & 0.00 & 0.01 & 0.00 & - & 0.00 & 0.15 & 0.02 & 0.01 & 0.01 & 0.48 & 0.00 & 0.56 & 0.09 & 0.00 \\
PHL & 0.23 & 0.00 & 0.00 & 0.00 & 0.00 & 0.00 & - & 0.01 & 0.00 & 0.00 & 0.03 & 0.00 & 0.02 & 0.07 & 0.09 & 0.00 \\
SGP & 0.00 & 0.00 & 0.00 & 0.00 & 0.00 & 0.00 & 0.00 & - & 0.00 & 0.00 & 0.00 & 0.00 & 0.00 & 0.00 & 0.00 & 0.00 \\
THA & 0.47 & 0.00 & 0.02 & 0.03 & 0.00 & 0.04 & 0.01 & 0.00 & - & 0.03 & 0.05 & 0.26 & 0.00 & 0.01 & 0.01 & 0.01 \\
VNM & 0.38 & 0.00 & 0.00 & 0.00 & 0.00 & 0.01 & 0.00 & 0.02 & 0.00 & - & 0.00 & 0.23 & 0.03 & 0.04 & 0.06 & 0.00 \\
\hline AUS & 0.01 & 0.00 & 0.01 & 0.00 & 0.00 & 0.00 & 0.00 & 0.00 & 0.00 & 0.00 & - & n.a. & - & n.a. & n.a. & n.a. \\
CHN & 0.01 & 0.00 & 0.00 & 0.00 & 0.00 & 0.00 & 0.00 & 0.00 & 0.00 & 0.00 & n.a. & - & - & - & n.a. & n.a. \\
IND & 0.03 & 0.00 & 0.00 & 0.02 & 0.00 & 0.00 & 0.00 & 0.00 & 0.00 & 0.00 & - & - & - & n.a. & n.a. & - \\
JPN & 0.00 & 0.00 & 0.00 & 0.00 & 0.00 & 0.00 & 0.00 & 0.00 & 0.00 & 0.00 & n.a. & - & n.a. & - & - & - \\
KOR & 0.07 & 0.00 & 0.00 & 0.00 & 0.00 & 0.01 & 0.00 & 0.03 & 0.00 & 0.01 & n.a. & n.a. & n.a. & - & - & n.a. \\
NZL & 0.05 & 0.00 & 0.00 & 0.01 & 0.00 & 0.01 & 0.00 & 0.00 & 0.02 & 0.01 & n.a. & n.a. & - & - & n.a. & - \\
\hline
\end{tabular}

Source: Authors' simulations

\begin{tabular}{|c|c|c|c|c|c|c|c|c|c|c|c|c|c|c|c|c|}
\hline \multirow[t]{2}{*}{ Importers } & \multirow[t]{2}{*}{ Ave. } & \multicolumn{15}{|c|}{ Exporters } \\
\hline & & BRN & KHM & IDN & LAO & MYS & PHL & SGP & THA & VNM & AUS & CHN & IND & JPN & KOR & NZL \\
\hline BRN & 36.9 & - & 62.6 & 69.5 & 0.0 & 50.3 & 51.9 & 14.6 & 89.3 & 5.0 & 12.4 & 24.7 & 39.5 & 80.3 & 89.0 & 22.7 \\
\hline КНM & 78.7 & 96.3 & - & 100.8 & 100.0 & 100.1 & 100.1 & 100.0 & 99.9 & 100.0 & 43.8 & 68.6 & 64.6 & 2.7 & 31.1 & 1.2 \\
\hline IDN & 26.2 & - & 96.9 & - & - & 70.2 & 0.0 & 1.5 & 0.4 & 0.0 & 85.2 & 17.9 & 4.4 & 44.4 & 52.3 & n.s. \\
\hline LAO & 73.4 & - & 2.4 & n.s. & - & 23.6 & 1.3 & 9.2 & 32.0 & 55.1 & 59.3 & 96.7 & 86.1 & n.s. & n.s. & 94.2 \\
\hline MYS & 55.5 & 99.1 & 5.1 & n.s. & 100.0 & - & 0.5 & 79.8 & 31.4 & 18.8 & 74.2 & 68.0 & 5.6 & 72.8 & 20.1 & 69.7 \\
\hline PHL & 26.8 & - & - & 2.5 & - & 0.0 & - & 15.3 & 0.0 & 0.0 & 97.2 & 0.0 & 23.3 & 36.0 & 44.9 & n.s. \\
\hline SGP & - & - & - & - & - & - & - & - & - & - & - & - & - & - & - & - \\
\hline THA & 8.3 & 14.0 & 82.8 & 8.5 & 17.5 & 9.1 & 3.0 & 0.8 & - & 11.3 & 77.6 & 13.9 & 0.0 & 1.1 & 2.8 & 79.5 \\
\hline VNM & 10.4 & $\mathrm{n} . \mathrm{s}$ & n.s. & 8.9 & n.s. & 32.8 & 32.1 & 16.4 & n.s. & - & 2.2 & 9.6 & 15.8 & 23.1 & 7.3 & n.s. \\
\hline AUS & 100.0 & 0.0 & 100.0 & - & - & 100.0 & 100.0 & - & 100.0 & 100.0 & - & n.a. & - & n.a. & n.a. & n.a. \\
\hline $\mathrm{CHN}$ & 20.5 & 0.0 & 0.2 & n.s. & -3.0 & 5.9 & n.s. & 29.7 & 11.9 & 63.9 & n.a. & - & - & - & n.a. & n.a. \\
\hline IND & 3.2 & 0.0 & 0.0 & 3.6 & 0.0 & 1.5 & 34.1 & 6.0 & 5.2 & 2.5 & - & - & - & n.a. & n.a. & - \\
\hline JPN & n.s. & 0.0 & 68.6 & n.s. & 0.0 & 0.9 & n.s. & n.s. & 0.1 & 20.8 & n.a. & - & n.a. & - & - & - \\
\hline KOR & 11.1 & 91.7 & n.s. & 3.4 & 2.9 & 87.3 & n.s. & 97.4 & 2.8 & 3.9 & n.a. & n.a. & n.a. & - & - & n.a. \\
\hline NZL & 100.0 & 18.0 & 100.0 & 100.0 & - & 100.0 & 100.0 & - & 100.0 & 100.0 & n.a. & n.a. & - & - & n.a. & - \\
\hline
\end{tabular}

Those economy wide impacts of tariff removals will largely be determined by the magnitude of tariff reductions. The more tariff would be reduced, the more imports 
Chart 2 Tariff concessions: comparison of three measurements

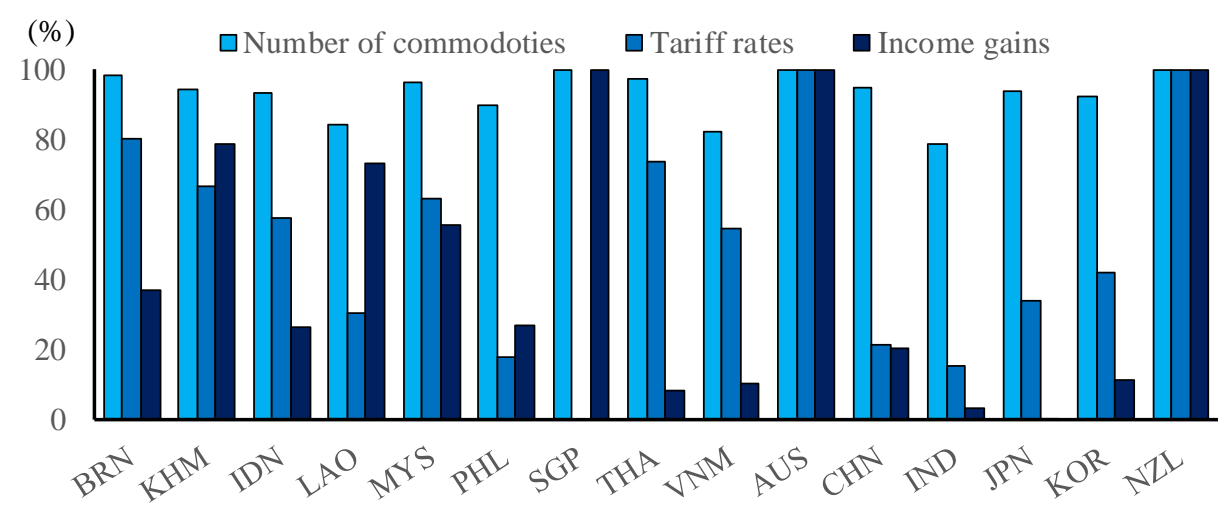

Source: Authors' estimates and simulations

would be boosted and domestic production may be replaced but the more real income and consumption could be stimulated by lower import costs on the other hand. The over-all impacts of unilateral tariff reductions would generally be expected to result in the improvements of economic welfare at the macro level.

Estimated income gains from full tariff removals by East Asian countries are shown in Table 7 by the source countries of imports. Those magnitudes vary widely among ASEAN countries reflecting the differences in initial tariff rates discussed above and other six countries (Australia, China, India, Japan, Korea and New Zealand) would gain less than AESAN countries. In contrast, income gains from remaining tariff reductions according to East Asian EPAs (Table 8) would generally be limited except smaller East Asian countries as a result of major implementation of existing EPAs until 2011. The ratios of income gains by remaining tariff reductions according to existing East Asian EPAs relative to those by full tariff removals are shown in Table 9. It is indicated in Chart 2 that those are more or less proportional to the rates of tariff concessions in terms of trade weighted average tariff rates (Table 4) rather than those at tariff line levels (Table 1).

That said, the ratio of tariff concessions in terms of income gains as well as trade weighted average tariff rates would not be substantially high enough as those in terms of number of commodities at tariff line levels. As discussed above, final tariff rates after implementing existing EPAs would not be so much lower.

Moreover, the differences in those tariff concessions are observed both at average ratios among East Asian countries and according to trade partners of individual 
Table 10 Income gains from East Asian tariff reductions

\begin{tabular}{lrrrr} 
& & & & (\% of GDP, \%) \\
& From 2011 & Past EPAs & Additional & Past ratio \\
\hline Brunei & 5.3 & 2.2 & 3.1 & 41.5 \\
Cambodia & 11.0 & 8.1 & 3.0 & 73.5 \\
Indonesia & 2.2 & 0.4 & 1.8 & 17.0 \\
Lao & 4.2 & 1.3 & 2.9 & 31.1 \\
Malaysia & 3.8 & 1.6 & 2.2 & 41.7 \\
Philippines & 0.9 & 0.3 & 0.5 & 39.6 \\
Singapore & 2.9 & 0.8 & 2.0 & 29.6 \\
Thailand & 6.4 & 0.6 & 5.8 & 10.1 \\
Viet Nam & 6.1 & 1.3 & 4.8 & 21.3 \\
\hline Australia & 1.6 & 0.1 & 1.5 & 5.2 \\
China & 0.6 & 0.0 & 0.6 & 3.5 \\
India & 1.6 & 0.0 & 1.6 & -0.1 \\
Japan & 1.6 & 0.1 & 1.5 & 6.4 \\
Korea & 5.3 & 0.1 & 5.2 & 1.9 \\
New Zealand & 1.9 & 0.2 & 1.8 & 8.6 \\
\hline Source: Auths
\end{tabular}

Source: Authors' simulations

East Asian countries reflecting specific trade structure.

The income gains from tariff reductions according to RCEP are also compared among ASEAN and other six countries in Table 10. It is suggested that ASEAN countries have already committed major tariff reductions within ASEAN and in ASEAN+1 EPAs in the past. Income gains of ASEAN countries from existing East Asian EPAs are estimated to account for 10 to 70 per cent of full tariff removals. However, additional income gains from full tariff removals would still be sizable. On the other hand, other six countries would benefit much more from future RCEP. East Asian countries as a whole would remain benefit largely from future trade liberalization in the region. In order to estimate such impacts of future EPAs, accurate baselines for tariff rates will be essential.

\section{Conclusion}

Standard data and modelling approaches in global trade analysis do not factor in the tariff concessions that have actually being implemented in reality, apart from the conventional FTAs. This may have a tendency to overestimate the macro-economic and sectoral effects of FTAs in the future. We address this problem in this paper, focusing on East Asia and Pacific. 115 out of 120 possible combinations of bilateral agreements in East Asia are already covered by EPAs concluded or implemented. Those East Asian 
EPAs have "substantially covered" various commodities for tariff reductions ranging from around 80 per cent in India to 100 per cent in Singapore, Australia and New Zealand measured in terms of tariff lines at HS 6 digit levels.

That said, tariff reductions in East Asia vary significantly in terms of the initial and final levels of tariff rates as well as the degrees of tariff cuts. By sectors, the least significant declines in tariff concern agricultural products and especially the sectors in which initial protection was strongest. Tariff concessions in East Asian EPAs have not substantially been high enough in terms of trade weighted average tariff rates those would be much more effective in economics than number of commodities.

The ratios of income gains by remaining tariff reductions according to existing East Asian EPAs relative to those by full tariff removals indicate that those are more or less proportional to the rates of tariff concessions in terms of average tariff rates rather than those at tariff line levels. East Asian countries would remain benefit largely from future trade liberalization in the region. In order to estimate such impacts of future EPAs, accurate baselines for tariff rates will be essential. 


\section{Bibliography}

Itakura, Ken and Hiro Lee (2012), "Welfare Changes and Sectoral Adjustments of Asia-Pacific Countries under Alternative Sequencings of Free Trade Agreements, OSIPP Discussion Paper: DP-2012-E-005, Osaka University.

Kawasaki, Kenichi (2015), "The Relative Significance of EPAs in Asia-Pacific", Journal of Asian Economics, Volume 39, Elsevier, August 2015

Kuno, Arata (2011) "Constructing the tariff dataset for the ERIA FTA database“, in C.J. Lee and M. Okabe (eds.) Comprehensive Mapping of FTAs in ASEAN and East Asia, ERIA Research Project Report 2010-26, ERIA, Jakarta, pp. 13-37.

Kuno, Arata, Yoshifumi Fukunaga, and Fukunari Kimura. (Forthcoming) "Pursuing a Consolidated Tariff Structure in the RCEP: Sensitivity and Inconsistency in ASEAN's Trade Protection.” In Christopher Findlay ed. ASEAN and Regional Free Trade Agreements. (Routledge-ERIA Studies in Development Economics), Routledge.

Narayanan, G., Badri, Angel Aguiar and Robert McDougall, Eds. (2015). Global Trade, Assistance, and Production: The GTAP 9 Data Base, Center for Global Trade Analysis, Purdue University, West Lafayette, Indiana.

Petri A. Petri, Michael G. Plummer and Fan Zhai (2012), The Trans-Pacific Partnership and Asia-Pacific Integration: A Quantitative Assessment, Policy Analyses in International Economics 98, Peterson Institute for International Economics, Washington DC.

USITC (2016), Trans-Pacific Partnership Agreement: Likely Impact on the U.S. Economy and on Specific Industry Sectors, the Unites States International Trade Commission (USITC), May 2016 


\section{Annex Incorporation of Tariff Concessions data into GTAP Data}

Using the adjusted tariff dataset prepared from the ITC/CEPII MacMAP dataset, we modify GTAP Data Base. This is done by using Altertax tool, which is described in Malcolm (1998). It involves the following steps:

Firstly, we compute the shocks in power of tariffs required to modify the tariff rates in GTAP Data Base into those implied in the adjusted tariff dataset. Powers of tariffs are defined as the ratio of Value of Imports at Market Prices (VIMS) to Value of Imports at World Prices (VIWS); the difference between these two values is the tariff revenue. The alternative and equivalent way of calculating power of tariffs is $(1+$ tariff rates). We use this method to calculate the adjusted power of tariffs.

Secondly, we turn to the standard GTAP model and define a closure that changes nothing much in the data other than the matrix involving the Value of Imports at Market Prices (VIMS). Shocking the tariffs in the standard GTAP model closure would change a lot of prices and quantities, since this would be a tariff reduction policy exercise. Such a situation should be avoided, since we merely want to change the tariff rates, nothing else in the data. This is why we use this alternative closure, which essentially fixes the ratio of change in trade balance to income and uses unitary elasticities across the board.

Thirdly, we run the simulation of shocks calculated in the first step within the closure defined in the second step, in the standard GTAP model. We employ the final VIMS matrix from the updated data of this simulation, to replace the VIMS in GTAP Data Base for our policy simulations. 


\section{Appendix}

Table A1 Average AVEs of MFN tariffs, 2011

(\%)

\begin{tabular}{|c|c|c|c|c|c|c|c|c|c|c|c|c|c|c|c|c|}
\hline \multirow[t]{2}{*}{ Importers } & \multirow[t]{2}{*}{ Ave." } & \multicolumn{15}{|c|}{ Exporters } \\
\hline & & BRN & KHM & IDN & $\mathrm{LAO}$ & MYS & PHL & SGP & THA & VNM & AUS & $\mathrm{CHN}$ & IND & JPN & KOR & NZL \\
\hline BRN & 4.0 & - & 2.1 & 7.8 & 4.4 & 4.7 & 6.8 & 4.3 & 7.4 & 1.7 & 2.6 & 4.6 & 0.4 & 8.0 & 2.3 & 1.8 \\
\hline КНM & 11.6 & 14.2 & - & 6.5 & 13.9 & 11.7 & 11.1 & 15.6 & 12.7 & 12.9 & 10.8 & 10.1 & 8.3 & 16.5 & 11.1 & 11.2 \\
\hline IDN & 5.4 & 0.1 & 10.8 & - & 6.5 & 3.7 & 5.3 & 3.0 & 10.5 & 6.0 & 4.6 & 5.8 & 5.3 & 7.2 & 4.7 & 4.4 \\
\hline LAO & 13.7 & 9.7 & 20.5 & 11.7 & - & 10.3 & 8.9 & 24.5 & 13.6 & 11.9 & 7.6 & 11.4 & 16.2 & 19.8 & 24.7 & 6.3 \\
\hline MYS & 6.1 & 3.8 & 12.9 & 6.7 & 0.9 & - & 3.7 & 3.2 & 8.8 & 8.1 & 2.6 & 6.0 & 4.4 & 8.9 & 6.4 & 2.6 \\
\hline PHL & 6.3 & 0.5 & 10.0 & 9.6 & 5.4 & 4.3 & - & 2.1 & 13.3 & 29.2 & 4.1 & 4.8 & 8.7 & 4.1 & 2.9 & 3.8 \\
\hline SGP & 0.1 & 0.0 & 0.0 & 0.0 & 0.1 & 0.1 & 0.0 & - & 0.1 & 0.3 & 0.1 & 0.0 & 0.1 & 0.0 & 0.0 & 0.0 \\
\hline THA & 7.4 & 0.1 & 14.0 & 8.9 & 2.9 & 5.7 & 10.1 & 6.2 & - & 9.1 & 3.1 & 6.8 & 7.8 & 8.8 & 6.2 & 8.5 \\
\hline VNM & 8.7 & 0.0 & 7.7 & 11.0 & 1.8 & 9.6 & 7.5 & 10.9 & 11.9 & - & 3.5 & 9.2 & 9.3 & 5.9 & 7.0 & 4.8 \\
\hline AUS & 2.5 & 0.0 & 8.4 & 2.3 & 0.4 & 1.6 & 2.9 & 0.8 & 6.3 & 1.1 & - & n.a. & - & n.a. & n.a. & n.a. \\
\hline $\mathrm{CHN}$ & 4.9 & 0.3 & 10.9 & 4.3 & 2.3 & 3.1 & 2.0 & 4.1 & 6.5 & 15.2 & n.a. & - & - & - & n.a. & n.a. \\
\hline IND & 18.6 & 0.1 & 45.1 & 31.6 & 2.1 & 20.3 & 5.9 & 6.3 & 10.3 & 11.3 & - & - & - & n.a. & n.a. & - \\
\hline JPN & 2.4 & 0.0 & 31.0 & 0.9 & 9.5 & 0.8 & 2.8 & 3.6 & 5.5 & 3.6 & n.a. & - & n.a. & - & - & - \\
\hline KOR & 5.5 & 3.0 & 14.9 & 3.2 & 1.6 & 3.5 & 5.6 & 2.7 & 14.4 & 13.0 & n.a. & n.a. & n.a. & - & - & n.a. \\
\hline NZL & 1.3 & 0.0 & 8.8 & 1.8 & 4.0 & 0.9 & 1.4 & 0.8 & 3.1 & 2.7 & n.a. & n.a. & - & - & n.a. & - \\
\hline
\end{tabular}

Source: ITC's MAcMap database, trade weighted average, \%. Authors' calculations.

Table A2 Number of tariff peaks, by importing country and large sectors

\begin{tabular}{cccc|cccc}
\hline \multicolumn{5}{c}{ ASEAN COUNTRIES } & \multicolumn{5}{c}{ ASEAN's PARTNERS } \\
\hline Importer & Sector & TP_2011 & TP_2025 & Importer & Sector & TP_2011 & TP_2025 \\
\hline BRN & ALL & 255 & 129 & AUS & ALL & 8 & \\
BRN & Agriculture & 250 & 128 & AUS & NAMA & 8 & \\
BRN & NAMA & 5 & 1 & CHN & ALL & 410 & 389 \\
IDN & ALL & 262 & 235 & CHN & Agriculture & 287 & 278 \\
IDN & Agriculture & 247 & 230 & CHN & NAMA & 123 & 111 \\
IDN & NAMA & 15 & 5 & IND & ALL & 1,360 & 1,155 \\
KHM & ALL & 13,328 & 1,006 & IND & Agriculture & 753 & 753 \\
KHM & Agriculture & 3,276 & 213 & IND & NAMA & 607 & 402 \\
KHM & NAMA & 10,052 & 793 & JPN & ALL & 779 & 746 \\
LAO & ALL & 1,320 & 956 & JPN & Agriculture & 759 & 726 \\
LAO & Agriculture & 963 & 739 & JPN & NAMA & 20 & 20 \\
LAO & NAMA & 357 & 217 & KOR & ALL & 1,416 & 1,353 \\
MYS & ALL & 797 & 639 & KOR & Agriculture & 1,405 & 1,351 \\
MYS & Agriculture & 392 & 392 & KOR & NAMA & 11 & 2 \\
MYS & NAMA & 405 & 247 & NZL & ALL & 6 & \\
PHL & ALL & 210 & 210 & NZL & NAMA & 6 & \\
PHL & Agriculture & 210 & 210 & & & & \\
THA & ALL & 1,946 & 314 & & & & \\
THA & Agriculture & 1,414 & 234 & & & & \\
THA & NAMA & 532 & 80 & & & & \\
VNM & ALL & 1,339 & 669 & & & & \\
VNM & Agriculture & 460 & 197 & & & & \\
VNM & NAMA & 879 & 472 & & & & \\
\hline SO & & & & & \\
\end{tabular}

Source: ITC's MAcMap database 